\title{
Introducing Systematic Screening to Reduce Unmet Health Needs: A Manager's Manual
}

Ricardo Vernon

James R. Foreit

Population Council

Emma Ottolenghi

Follow this and additional works at: https://knowledgecommons.popcouncil.org/departments_sbsr-rh

Part of the Demography, Population, and Ecology Commons, Family, Life Course, and Society Commons, International Public Health Commons, and the Medicine and Health Commons How does access to this work benefit you? Let us know!

\section{Recommended Citation}

Vernon, Ricardo, James R. Foreit, and Emma Ottolenghi. 2008. "Introducing Systematic Screening to Reduce Unmet Health Needs: A Manager's Manual." Washington, DC: Population Council. 


\title{
Introducing Systematic Screening to Reduce Unmet Health Needs: A Manager's Manual
}

\author{
Ricardo Vernon
}

\section{James R. Foreit}

\section{Emma Ottolenghi}

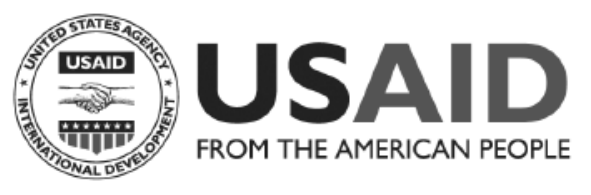

\section{Population Council FRONTIERS}

This publication was funded by the U.S. AGENCY FOR INTERNATIONAL DEVELOPMENT (USAID) under the terms of Cooperative Agreement Number HRN-A-00-98-00012-00. The opinions expressed herein are those of the author and do not necessarily reflect the views of USAID. 


\section{Population Council}

The Population Council is an international, nonprofit, nongovernmental institution that seeks to improve the well-being and reproductive health of current and future generations around the world and to help achieve a humane, equitable, and sustainable balance between people and resources. The Council conducts biomedical, social science, and public health research and helps build research capacities in developing countries. Established in 1952, the Council is governed by an international board of trustees. Its New York headquarters supports a global network of regional and country offices.

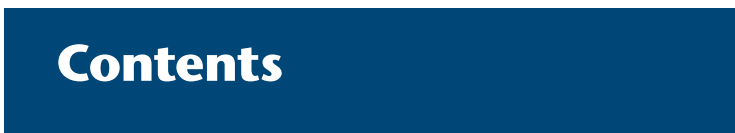

This manual

How to implement

systematic screening

2

References

8

Appendix:

Sample training plan

9

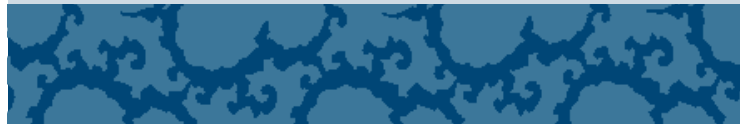

\section{Frontiers in Reproductive Health}

The Frontiers in Reproductive Health Program (FRONTIERS) applies systematic research techniques to improve delivery of family planning and reproductive health services and influence related policies. FRONTIERS is funded by the U.S. Agency for International Development (USAID) and led by the Population Council in collaboration with Family Health International. FRONTIERS staff and collaborating organizations conduct operations research in Africa, Asia and the Near East, Eastern Europe, and Latin America and the Caribbean.

Frontiers in Reproductive Health Program (FRONTIERS) Population Council

4301 Connecticut Ave. NW, Suite 280

Washington, DC 20008 USA

Telephone: (202) 237-9400

Facsimile: (202) 237-8410

E-mail: frontiers@pcdc.org

www.popcouncil.org/frontiers

This publication was made possible through support provided by USAID under the terms of Cooperative Agreement No. HRN-A-00-98-00012-00. The opinions expressed herein do not necessarily reflect the views of USAID.

Revised 2008

(c) 2006 the Population Council, Inc.

This publication may be reproduced in whole or in part without permission of Population Council provided full source citation is given and the reproduction is not for commercial purposes.

Suggested citation: Vernon, Ricardo, James R. Foreit, and Emma Ottolenghi. 2008. "Introducing Systematic Screening to Reduce Unmet Health Needs: A Manager's Manual," FRONTIERS Manual, revised edition. Washington, DC: Population Council. 


\section{This manual}

This manual is designed to help program decisionmakers, managers, supervisors, and providers to introduce systematic screening in their health services. Systematic screening can improve women's health by addressing multiple unmet needs for reproductive and other health services. This manual provides the information and tools needed for adding systematic screening to your program:

- The activities necessary to implement systematic screening.

now to select facilities, services to screen for, and who will screen.

- Systematic screening checklist development, adaptation, and pre-testing, with examples.

- Advice for training screeners/providers and supervisors and an outline of a generic training agenda.

The contents of the manual may be adapted to reflect local, national, or programmatic health priorities and resources as well as to promote the use of underutilized preventive services.

\section{The problem: Unmet need for reproductive health services}

Most women attending clinics have multiple needs for preventive and curative reproductive and child health services. These may include antenatal and postpartum care, family planning, well-baby care and immunization, health and nutritional assessments, cervical cancer preventive services and screening, and detection and treatment for sexually transmitted infections and HIV. Generally, providers deliver only the service requested by the client, and clients may be unaware that they could benefit from additional services or that the needed services are available. As a result, the client leaves the facility with unmet reproductive health needs, and the service provider misses an opportunity to render those services.

\section{A solution: Integration of reproductive health services at the provider level}

The 1994 Cairo International Conference on Population and Development (ICPD) Program of Action recommended the delivery of integrated reproductive health services. We define integration as the proactive provision of multiple reproductive health services in the same facility at the same time (Foreit, Hardee, and Agarwal 2002). A solution to the problem of lack of integration is to identify the client's needs and desires for reproductive health services when she first arrives for a clinic visit, and to provide those services to her either during the same visit, at a scheduled subsequent visit, or through referral to another facility.

\section{Systematic screening: A simple tech- nique for effective integration}

Systematic screening has been designated a best practice by USAID. The technique consists of three steps:

1. Use a standardized instrument (set of questions) to identify each client's needs for additional reproductive and child health services.

2. If available at the time, offer identified services during the same visit, or:

3. Offer a future appointment or referral for those services that cannot be provided immediately.

\section{Evidence: Systematic screening works}

- Clients' unmet needs decrease. In Mexico, the rate of vaccination increased from 4 to 33 percent among children not originally presenting at the health center for this service (Vernon and Foreit 1999).

- The number of services per visit increases after systematic screening is introduced into a program. In studies in Africa, Asia, and Latin America, systematic screening increased services per visit by 9 to 28 percent, depending on the site. The large increases in service utilization and the similarity of these results, shown in Table 1 on the next page, demonstrate that systematic screening can be effective in different countries, programs, and settings. 
Table 1.

\section{Effectiveness of systematic screening in increasing services per visit: Non-screened women versus screened women}

\begin{tabular}{|lccc|}
\hline Country & $\begin{array}{c}\text { Services } \\
\text { per visit: } \\
\text { women } \\
\text { not } \\
\text { screened }\end{array}$ & $\begin{array}{c}\text { Services } \\
\text { per visit: } \\
\text { women } \\
\text { screened }\end{array}$ & $\begin{array}{c}\text { Differ- } \\
\text { ence } \\
(\%)\end{array}$ \\
\hline Bolivia & 1.1 & 1.2 & 9 \\
\hline Honduras & 1.1 & 1.3 & 18 \\
\hline Peru & 1.6 & 1.8 & 13 \\
\hline $\begin{array}{l}\text { India } \\
\text { (large clinics) }\end{array}$ & 1.6 & 2.0 & 25 \\
(small clinics) & 1.5 & 1.6 & 7 \\
\hline $\begin{array}{l}\text { Senegal } \\
\text { (urban clinics) }\end{array}$ & 1.2 & 1.4 & 17 \\
(rural posts) & 1.4 & 1.8 & 28 \\
\hline
\end{tabular}

Sources: Foreit, Vernon, and Riveros 2005; León et al. 1998; Das et al. 2005; Sanogo et al. 2005; Vernon et al. 2005.

- Most identified unmet needs result in the provision of additional services. In India 96 percent resulted in additional services, mostly family planning. The services actually provided differed by setting and screening strategy.

- Making one visit rather than multiple visits for needed services reduces client costs and time.

a The increase in the number of services provided per visit implies an improvement in provider productivity (see Brambila and Solórzano 1998). In areas where the unmet need for reproductive health services is high and provider productivity is low, screening is an efficient and cost-effective alternative to outreach services.

- Clinic revenues can increase from additional services provided. A small clinical program in Peru increased revenues by about US $\$ 42,000$ per year using systematic screening (León et al. 1998).

Because it has been successful in increasing the number of priority services provided, systematic screening has been incorporated into programs in Guatemala, India, and Senegal, and has been used to screen for many different kinds of service needs.

\section{How to implement systematic screening}

The essential activities you need to implement the systematic screening strategy are outlined below:

\section{Put someone in charge of the screen- ing effort}

Innovations often fail because of the lack of a person in charge-someone who is responsible for making sure the innovation is implemented as planned. You should put someone in charge of the overall screening program and someone in charge of the program in each facility.

At the program level the coordinator has the responsibility for developing the screening form, organizing screening, training staff, supervising the intervention, and reporting screening results to key program decisionmakers.

At the facility level someone must be responsible for ensuring that screening forms are available, that all current and new staff are trained in the technique, and that providers are actually screening clients. A supervisor should be the responsible person in cases where there are multiple small clinics with only one provider.

\section{Decide what you will screen for}

- Screen for only a few priority services for which there is a large unmet need. Preferably screen for those with clear health benefits and where service provision is possible at all times (i.e., where supplies and trained staff exist) but is underutilized (i.e., where there is low demand and excess capacity for providing services).

- Do not screen for too many service needs. The procedure will take too long, become too complicated, and possibly discourage staff from screening. Long interviews can also frustrate clients. In addition, when a large number of service needs are identified, the woman may not have the time or resources to receive them. Note that the form presented here is designed for services for women and children, but it could be designed for services offered for men as well. 


\section{Choose only suitable facilities}

Not all service delivery sites are suitable for systematic screening. Systematic screening is especially effective in underutilized clinics where it can raise the productivity of the facility. On the other hand, clinics operating at full capacity cannot implement this strategy without increasing provider time, resources, or client waiting time.

Systematic screening can be implemented in facilities that:

- Provide more than one health service at the same time.

- Have providers trained in the services you wish to offer and the necessary supplies to deliver these services.

- Are not over-crowded or do not turn away clients seeking services.

- Have predictable slow periods. Often, clinics are crowded at certain times of the day and not at others. In this case, you may decide to use systematic screening only when there are fewer clients waiting for services.

\section{Study patient flow before setting up the screening system and deciding how screening will take place}

To implement systematic screening, you need to identify the path followed by clients in facilities and then decide who will screen, when it will be done, and how it will be done.

Small clinics: Often, there is only one provider in small clinics and health posts. This provider is the only client contact point and should conduct all screening.

Large clinics: Usually, there are different providers for different services. The first provider seen by the client may be charged with the screening process and made responsible for directing the client to other providers. Thus, all first contact service providers will need training in the use of the screening instrument. Alternatively, you may decide that clients will be screened at the reception point if it is not too crowded and auditory privacy for the client can be assured. After screening by the receptionist, the client receives a slip of paper indicating the needed services and is informed where the appropriate provider is located.

\section{Design a new form or adapt an exist- ing screening instrument to identify needed services}

The screening instrument is a form used to identify services that a client may need. One example of a systematic screening instrument is shown on the next page. Some programs choose to use paper forms to gather information on individual clients by sending the form with the client from provider to provider, recording the needs detected and the services provided. An advantage of paper forms is that they can be used for internal referral. A disadvantage is that stock-outs of forms can occur. Other programs take a less costly approach and use forms made of plastic or heavy cardboard that are used multiple times by the provider. One disadvantage of this approach is that because the instruments stay with the provider, it may be harder to monitor the amount of screening taking place.

Whichever type of form is used, it should:

- Be used for all clients meeting predetermined criteria and be used in the same way for all clients.

- Screen for a few unmet needs.

- Include instructions for screening.

- Identify the service the client came to the clinic for before screening for other unmet needs.

- Use only yes or no answers.

- List the services for which clients are screened.

- Be short and easy enough to allow providers to screen clients within five minutes. With practice in its use, the provider will complete the process in a shorter time.

Figure 1 is a form that was successfully tested in India and Senegal. This form includes every question that needs to be asked and the sequence in which questions should be asked. 
Figure 1. Checklist used in India and Senegal

\begin{tabular}{|c|c|c|c|c|c|}
\hline \multicolumn{6}{|c|}{ Screening Instrument } \\
\hline \multicolumn{6}{|c|}{ Today's date: } \\
\hline \multicolumn{2}{|c|}{$\begin{array}{l}\text { How old are } \\
\text { you? }\end{array}$} & \multicolumn{4}{|c|}{$\begin{array}{l}\text { Administer checklist only if woman is between } 15-44 \text { years of age. If she is not between } 15-44 \text {, } \\
\text { thank her and terminate the interview. }\end{array}$} \\
\hline \multicolumn{5}{|c|}{ To be filled in by screener } & Provider \\
\hline \multicolumn{3}{|c|}{$\begin{array}{l}\text { Screening Questions } \\
\text { Note: Be sure to include reason for } \\
\text { visit in required services. }\end{array}$} & Follow-Up Questions & $\begin{array}{l}\text { Discuss } \\
\text { and Circle } \\
\text { Requested } \\
\text { Service(s) }\end{array}$ & $\begin{array}{l}\text { Service } \\
\text { Outcome }\end{array}$ \\
\hline \multicolumn{3}{|c|}{ What is the reason for today's visit? } & \multicolumn{2}{|l|}{ Reason for the visit: } & $\begin{array}{l}\text { 1. Provided } \\
\text { 2. Scheduled } \\
\text { 3. Referral }\end{array}$ \\
\hline 1 & \multicolumn{2}{|c|}{$\begin{array}{l}\text { Are you pregnant? } \\
\text { 1. Yes } \rightarrow \\
\text { 2. No: go to } 2\end{array}$} & $\begin{array}{l}\text { Are you attending a prenatal clinic? } \\
\text { 1. No } \rightarrow \\
\text { 2. Yes: go to } 5\end{array}$ & $\begin{array}{l}\text { Prenatal Care } \\
\text { and go to } 5\end{array}$ & $\begin{array}{l}\text { 1. Provided } \\
\text { 2. Scheduled } \\
\text { 3. Referral }\end{array}$ \\
\hline 2 & \multicolumn{2}{|c|}{$\begin{array}{l}\text { Are you trying to get pregnant? } \\
\text { 1. No } \rightarrow \\
\text { 2. Yes: go to } 4\end{array}$} & $\begin{array}{l}\text { Are you using a contraceptive method? } \\
\text { 1. No } \rightarrow \\
\text { 2. Yes: go to } 3\end{array}$ & $\begin{array}{l}\text { Family Planning } \\
\text { and go to } 4\end{array}$ & $\begin{array}{l}\text { 1. Provided } \\
\text { 2. Scheduled } \\
\text { 3. Referral }\end{array}$ \\
\hline 3 & \multicolumn{2}{|c|}{$\begin{array}{l}\text { Are you happy with your } \\
\text { contraceptive method? } \\
\text { 1. No } \rightarrow \\
\text { 2. Yes: go to } 4\end{array}$} & $\begin{array}{l}\text { Would you like to use another } \\
\text { contraceptive method? } \\
\text { 1. Yes } \rightarrow \\
\text { 2. No: go to } 4\end{array}$ & $\begin{array}{l}\text { Family Planning } \\
\text { and go to } 4\end{array}$ & $\begin{array}{l}\text { 1. Provided } \\
\text { 2. Scheduled } \\
\text { 3. Referral }\end{array}$ \\
\hline 4 & \multicolumn{2}{|c|}{$\begin{array}{l}\text { When did you have your last pap } \\
\text { smear for cervical cancer? } \\
\text { 1. DK/more than } 3 \text { years ago } \rightarrow \\
\text { 2. Less than } 3 \text { years ago: go to } 5\end{array}$} & $\begin{array}{l}\text { Would you like to have a } \\
\text { pap smear today? } \\
\text { 1. Yes } \rightarrow \\
\text { 2. No: go to } 5\end{array}$ & $\begin{array}{l}\text { Pap Smear } \\
\text { and go to } 5\end{array}$ & $\begin{array}{l}\text { 1. Provided } \\
\text { 2. Scheduled } \\
\text { 3. Referral }\end{array}$ \\
\hline 5 & \multicolumn{2}{|c|}{$\begin{array}{l}\text { Do you have any children less } \\
\text { than } 5 \text { years of age? } \\
\text { 1. Yes } \rightarrow \\
\text { 2. No: go to } 7\end{array}$} & $\begin{array}{l}\text { Are you taking them in for well child } \\
\text { services and growth monitoring? } \\
\text { 1. No } \rightarrow \\
\text { 2. Yes: go to } 6\end{array}$ & $\begin{array}{l}\text { Growth and } \\
\text { Development } \\
\text { Evaluation } \\
\text { and go to } 6\end{array}$ & $\begin{array}{l}\text { 1. Provided } \\
\text { 2. Scheduled } \\
\text { 3. Referral }\end{array}$ \\
\hline 6 & \multicolumn{2}{|c|}{$\begin{array}{l}\text { Have all your children under age } 5 \\
\text { been completely vaccinated? } \\
\text { 1. No/DK } \rightarrow \\
\text { 2. Yes: go to } 7\end{array}$} & $\begin{array}{l}\text { Would you like to schedule vaccination } \\
\text { for your child(ren)? } \\
\text { 1. Yes } \rightarrow \\
\text { 2. No: go to } 7\end{array}$ & $\begin{array}{l}\text { Vaccination } \\
\text { and go to } 7\end{array}$ & $\begin{array}{l}\text { 1. Provided } \\
\text { 2. Scheduled } \\
\text { 3. Referral }\end{array}$ \\
\hline 7 & \multicolumn{2}{|c|}{$\begin{array}{l}\text { Is there any other service you } \\
\text { would like to receive today, or } \\
\text { would like to be referred for? } \\
\text { 1. Yes } \rightarrow \\
\text { 2. No: End interview }\end{array}$} & List service(s) & & $\begin{array}{l}\text { 1. Provided } \\
\text { 2. Scheduled } \\
\text { 3. Referral }\end{array}$ \\
\hline \multicolumn{6}{|c|}{ Observations (screener): } \\
\hline \multicolumn{6}{|c|}{ Observations (provider): } \\
\hline
\end{tabular}


This instrument consists of five columns and seven rows. The screener completes the questions in columns two through four, while the last column on service outcome is filled in by the provider. The form is designed to be attached to the client's clinical chart after screening so that the provider can complete the form (unless using a plastic or cardboard version of the form).

Screeners must be well trained in the use of the instrument. Depending on the answer given to questions in columns two and three, the screener may have to skip questions. For example, in question 2 , if the woman answers "yes" she is trying to get pregnant, the screener must skip to question 4 . On the other hand, if the woman answers "no" she is not trying to get pregnant, the screener moves to the next column in the same row and asks, "Are you using a contraceptive method?" If the answer is no, the screener moves to column four and circles Family Planning, then skips to question 4. Skips between questions are the most difficult tasks for interviewers to perform. Make sure that all screeners are especially well trained in following the correct skip pattern.

After completing the proper series of questions, the screener returns to column four and discusses the services that the woman wishes. If the client would like to receive the services during the same visit, the provider or screener provides the services and circles the service outcome ("provided") in the last column. If one or more needed services cannot be provided in the first consultation, the provider attaches the instrument to the clinical chart and sends the client with the chart to the next provider. If the screener is not the provider, the screener directs the client to the provider who will address the service by providing it, offering a future appointment, or giving a referral.

The screening form can be adapted to reflect local conditions and needs. University Research Co., LLC has adapted the form to include HIV services, including voluntary counseling and testing (VCT). It also notes that the client may not wish to accept family planning services or voluntary counseling and testing for HIV at this particular visit, but may accept a brochure (see Figure 2).

The screening form should be evaluated after a period of use to ensure its continuing relevance. If a given item fails to identify unmet needs for that service, it should be eliminated from the form and, if desired, replaced with another item to identify more current needs.

\section{Figure 2. Adapted systematic screening instrument questions}

\begin{tabular}{|l|l|l|l|l|}
\hline 2 & $\begin{array}{l}\text { Are you trying to get pregnant? } \\
\text { 1. No } \rightarrow \\
\text { 2. Yes: go to 4 }\end{array}$ & $\begin{array}{l}\text { Are you using a contraceptive } \\
\text { method? } \\
\text { 1. No } \rightarrow \text { and go to 4 } \\
\text { 2. Yes: go to 3 }\end{array}$ & $\begin{array}{l}\text { Family Planning } \\
\text { Accepted }\end{array}$ & $\begin{array}{l}\text { 1. Provided } \\
\text { 2. Scheduled } \\
\text { 3. Referral } \\
\text { brochure given }\end{array}$ \\
\hline 5 & $\begin{array}{l}\text { Have you been tested for HIV? } \\
\text { 1. No } \rightarrow \\
\text { 2. Yes: go to 6 }\end{array}$ & $\begin{array}{l}\text { Would you like to be tested for } \\
\text { HIV today? } \\
\text { 1. Yes } \rightarrow \\
\text { 2. No: go to 8 }\end{array}$ & $\begin{array}{l}\text { VCT/PMTCT } \\
\text { Accepted }\end{array}$ & $\begin{array}{l}\text { 1. Provided } \\
\text { 2. Scheduled } \\
\text { 3. Referral }\end{array}$ \\
\hline
\end{tabular}

Source: University Research Co., LLC 2006 adapted from Foreit 2006. 


\section{Pretest the form}

The only way to know if the form you have developed works in practice is to pretest it. Because the form might be difficult to administer for some screeners with limited literacy or working in crowded conditions, it is a good idea to pre-test two alternative forms and decide which works better in your specific program setting. Ask at least three providers to use each instrument with at least 10 clients and make sure to record the time it took to administer the form. If possible, observe the screenings. You may need to modify the form if some of the questions are difficult to ask, the skip pattern is not followed correctly on several occasions, the questions are misunderstood by the client, or if the form takes too long to complete.

\section{Note!}

When pretesting form with clinic clients, it is an obligation to provide each client with the services she has requested, either the same day, through a future appointment, or by referral.

\section{Create a user's manual}

After the form is pre-tested and finalized, a brief user's manual must be produced that explains the correct way to administer the instrument in terms that are understood by screeners.

\section{Provide adequate training}

Before training, hold a meeting with all facility staff to explain the changes in their work and the role each one will play. Listen and respond to their concerns and allow them to make suggestions on how to best to implement the new strategy.

Systematic screening is a very simple procedure that can be taught in a few hours. However, we do not recommend limiting training to the minimum time necessary. We have found that when the training period is very short, trainees tend not to take screening seriously and do not practice it with their clients. Training should last at least one full day, preferably two, and should cover the following topics:
- The importance of screening.

- The services that are being promoted by the screening.

n Use of the instrument (including role-play or practice in actual clinic setting).

- Rights of the client during the screening process (see box at right).

- Record-keeping and reporting procedures.

- How to schedule a return visit or make a referral.

Our experience shows that including a second day of training makes the systematic screening intervention more effective, as memory retention is better, and proper screening techniques are reinforced with more practice. We recommend that the second day be devoted to supervised practice with clinic clients in the staff's own work sites. At the end of the day, providers should be reconvened to discuss the needs detected, clients' responses to the offering of additional services, and any questions the providers may have about the technique.

Training is more effective when a relatively senior official of the organization introduces it. His or her presence is a signal that systematic screening is an important intervention that must be utilized by all trainees.

Supervisors also need to be trained, and they should be trained in the same sessions as the individuals who will be asked to do the screening. Also, more than one person must be trained per site. The client may see one of several providers at her first consultation (and screening); staff members may get sick, go on vacation, be transferred, or leave the post. Have someone ready to fill in if a regular screener does not come to work.

A training plan is shown in the Appendix. 


\section{Client rights during screening}

- The client has a right to confidentiality regarding her health status.

- The client has the right to refuse any service, including being screened.

- The clinic should provide adequate auditory privacy during screening.

- The client has the right to refuse to answer any question asked.

- The client must be given information about any service she requests.

\section{Supervise and monitor screening}

Job aids and new procedures like systematic screening often fail to be adopted by providers because of a lack of supervision and monitoring. Supervision will be improved if every facility has someone in charge of screening, and if some information is collected in the regular service statistics system on the number of persons screened. Obtaining the information may require an additional form, or preferably, another column in the routine provider or clinic reports. If your program includes community health committees, they should be involved in promoting and monitoring the intervention.
Especially during the first few months, it is important for the supervisor to ensure that clients are being screened and all screeners and providers are utilizing the form and correctly documenting the services provided. Periodically, the supervisor may perform a rapid evaluation by spending one full day in the clinic observing services and interviewing clients to verify that they were screened. Within the same day, the supervisor should discuss each observation with the observed provider, review any shortcomings, and congratulate the provider for work done correctly.

It is important to re-evaluate the screening form after a period of use. If a given item fails to identify unmet need for a service, it should be eliminated from the form and, if appropriate, replaced with another item for identifying the unmet need for other services. 


\section{References}

Brambila, C. and J. Solórzano. 1998. "Costos de las consultas de atención integral en salud reproductiva en Guatemala [Cost of integrated reproductive health care in Guatemala]," INOPAL III Working Paper No. 7. New York: Population Council.

Das, N. P. et al. 2005. "Systematic screening to meet unmet need by integrating reproductive health services: An operations research model to maximize service utilization," FRONTIERS Final Report. Washington, DC: Population Council.

Foreit, Karen G. Fleischman, Karen Hardee, and Kokila Agarwal. 2002. "When does it make sense to consider integrating STI and HIV services with family planning services?" International Family Planning Perspectives 28(2): 105-107.

Foreit, James R., Ricardo Vernon, and Patricia Riveros. 2005. "Use of systematic screening to increase the provision of reproductive health services in Bolivia," FRONTIERS Final Report. Washington, DC: Population Council.
Foreit, James R. 2003. "FRONTIERS operations research protocols: Providing more preventive reproductive health care through systematic screening," FRONTIERS Report. Washington, DC: Population Council.

León, Federico et al. 1998. "Increasing use of reproductive health services in a Peruvian clinic," in J. Foreit and T. Frejka (eds.), Family Planning Operations Research: A Book of Readings. New York: Population Council, 239-245.

Sanogo, D. et al. 2005. "Using systematic screening to increase integration of reproductive health services delivery in Senegal," FRONTIERS Final Report. Washington, DC: Population Council.

Vernon, Ricardo et al. 2005. "Systematic screening as a strategy to increase services integration and revenues in Honduras," FRONTIERS Final Report. Washington, DC: Population Council.

Vernon, Ricardo and James Foreit. 1999. "How to help clients obtain more preventive reproductive health care," International Family Planning Perspectives 25(4): 200-202. 


\section{Appendix}

\section{Sample training plan for providers and their supervisors}

The following is a training plan for screeners, health providers, and their supervisors. It outlines the desired outcomes of training in terms of knowledge and skills (training objectives), a sample training agenda, a sample screening form, and an example of a role-play. We cannot overstate the importance of repetition for mastering any new skill or methodology. The success of systematic screening relies on the provider's skill to use the screening instrument, so practice should be a priority during any training event.

Training objectives: Impart the knowledge and skills that providers and supervisors will need to apply systematic screening in their services:

\section{- Advantages of systematic screening.}

- Familiarity with each service or program in the clinic where they work: when are they available (day of week, time), who are the providers for each service, which services are being newly integrated with this intervention and, if this clinic charges for services, the charge for each service provided. In addition, providers need to know which services are available by a further appointment, and for which services clients need to be referred to another service delivery site or organization.

- Ethical issues: rights of the client during the screening process, including respecting clients' choice to be screened and to refuse any service the provider feels she needs. Privacy and confidentiality of information given by client must be ensured.

- Understanding of and ability to use the screening form-its purpose, question sequence, and skip patterns.

- Skills to use the screening form as designed and to completely fill in all necessary information.

- Record keeping and reporting procedures.

It must be clear to providers that, unless they are the only provider, they are not responsible for delivering all services themselves. They are responsible for screening clients for unmet needs and documenting these on the screening form as well as giving basic information about services to the client.
The success of the intervention depends on the consistent, accurate, and standardized use of the screening instrument with all women of reproductive age; therefore, before initiating the intervention, you must be assured that the provider has achieved competence in the above training objectives. In some cases, providers may need more supervised practice and longer time to complete training.

Training should last at least one full day, preferably two. As mentioned above, experience shows that including a second day of training makes the systematic screening intervention more effective, as memory retention is better and proper screening techniques are reinforced by repetition and practice. We recommend that the second day be devoted to supervised practice with clinic clients in the provider's own work site.

To avoid interrupting screening, if possible, train at least two providers or clinic staff members per clinic plus your supervisors.

Below is a sample training agenda for providers and their supervisors.

\section{Day 1}

The morning of the first day will be devoted to assuring the staff's thorough understanding of the intervention, the services provided in the participating clinics, and the screening form you have designed. Its use, the sequencing of questions, and skip patterns must be reviewed and explained until all trainees are clear on its application.

In the afternoon of the first day, the staff will practice using the screening instrument in a minimum of three role-plays. It is important to go over client rights during screening, which include:

- The client has the right to confidentiality.

- The client has the right to refuse any service.

- The clinic should provide adequate auditory privacy during the screening.

- The client has the right to refuse to answer any question asked.

- The client must be given information about any service she requests. 
A sample role-play is included at right. The trainers need to develop additional role-plays using profiles of typical clients who attend the clinic which include the need for specific services selected for integration. The profiles in the cases will allow the providers being trained to practice the questions in proper sequence and skip patterns correctly. The supervisor(s) also needs to attend the entire session and be trained in the use of the screening form along with the clinic staff.

\section{Sample systematic screening role-play exercise}

1. Divide the staff into groups of three persons: one will be the screener, one the client, and one the evaluator.

2. Give the "client" her profile (see example in box in next column) and allow her to study it for a couple of minutes. Instruct her to only tell the screener/provider about the service she came to the clinic for. The rest of the history must be revealed a piece at a time if the screener requests that information.

3. Provide the "screener" with a blank screening instrument, and ask her to conduct the screening and fill in the form.

4. The "evaluator" will be given a screening form that includes the correct steps based on the client profile, follow-up questions, and skips, and has the client's service needs recorded on it (see second screening form on page 12). She will highlight any steps that were not done correctly.

5. At the end of the role-play, the trainer will meet with each set of three staff members, assess their performance, and correct any misunderstandings or deficiencies.

6. Subsequently, in the same trio, the roles will be rotated with a new client profile.

Try to do this at least three times so each staff member will have a chance to evaluate a screening, be a client, and be a screener.

\section{Example of client profile for use by staff member role-playing as client \\ The client is a 27-year old woman in good health. \\ - She is attending the clinic today with her 9-month old daughter because she is due for her measles and rubella vaccine. \\ - She is not pregnant (had her menses 2 weeks ago) and does not wish to get pregnant. \\ - She is not using contraception. \\ - Her last pap smear was one year ago. \\ - She has another child, a 3-year old son, who came along with them today. \\ Her son's growth and development has not been evaluated because nobody offered this service. \\ - Her son has completed his immunization schedule.}

Notes on the screening form: Each question may be answered "yes" or "no," and the form leads the screener to a new question or to the service that needs to be provided, either by following an arrow or a skip pattern. For example, in question 2, if the woman answers "yes" she is trying to get pregnant, the screener skips to question 4 . On the other hand, if the woman answers "no" she is not trying to get pregnant, the screener remains in the second row and asks "Are you using a contraceptive method?" If the answer is no, the screener moves to column four and circles Family Planning, then skips to question 4. After completing the proper series of questions, the screener returns to column four and discusses the services that the woman wishes. If the client would like to receive the service, the screener attaches the instrument to the clinical chart, and passes it to the provider. The provider circles the appropriate service outcome ("provided," "scheduled," or "referred") in the last column. This last column may be eliminated so that the form remains with the provider. In this case, in clinics with several offices, the internal referral needs to be done in some other way, including verbally. 


\section{Screening Instrument (to be used by screener in role play)}

Today's date:

How old are you?

Administer checklist only if woman is between 15-44 years of age. If she is not between 15-44, thank her and terminate the interview.

\section{To be filled in by screener}

Provider

\section{Screening Questions}

Note: Be sure to include reason for

Follow-Up Questions

Discuss
and Circle
Requested
Service(s)

Service

visit in required services.

Service(s)

\section{Outcome}

What is the reason for today's visit?

Reason for the visit:

1. Provided

2. Scheduled

3. Referral

1 Are you pregnant?

Are you attending a prenatal clinic?

1. Yes $\rightarrow$

2. No: go to 2

1. No $\rightarrow$

2. Yes: go to 5

1. Provided

Prenatal Care

2. Scheduled

Are you trying to get pregnant?

Are you using a contraceptive method?

1. No $\rightarrow$

1. No $\rightarrow$

2. Yes: go to 4

2. Yes: go to 3

3. Referral

3 Are you happy with your contraceptive method?

Would you like to use another contraceptive method?

and go to 5

1. No $\rightarrow$

2. Yes: go to 4

1. Yes $\rightarrow$

2. No: go to 4

4 When did you have your last pap smear for cervical cancer?

Would you like to have a

pap smear today?

1. DK/more than 3 years ago $\rightarrow \quad$ 1. Yes $\rightarrow$

2. Less than 3 years ago: go to 5

2. No: go to 5

5 Do you have any children less than 5 years of age?

1. Yes $\rightarrow$

2. No: go to 7

Are you taking them in for well child services and growth monitoring?

1. No $\rightarrow$

2. Yes: go to 6

Family Planning 1. Provided and go to 4

2. Scheduled

3. Referral

Family Planning 1. Provided and go to 4

2. Scheduled

3. Referral

Pap Smear 1. Provided

and go to $5 \quad$ 2. Scheduled

3. Referral

6 Have all your children under age 5 Would you like to schedule vaccination been completely vaccinated? for your child(ren)?

1. No/DK $\rightarrow$

1. Yes $\rightarrow$

2. No: go to 7

2. Yes: go to 7

List service(s)

1. Provided

Growth and

2. Scheduled

Development

3. Referral

and 90 to 6

1. Provided

Vaccination

2. Scheduled

3. Referral

7 Is there any other service you would like to receive today, or would like to be referred for? and go to 7

1. Provided

2. Scheduled

1. Yes $\rightarrow$

2. No: End interview

3. Referral

Observations (screener):

Observations (provider):

After completing the screening, attach this form to the client's clinical chart or give it to her to present to the service provider. 


\section{Screening Instrument correctly filled in (to be used by evaluator in role play to document correctness of screening provider)}

\section{Today's date:}

How old are you? 27

Administer checklist only if woman is between 15-44 years of age. If she is not between 15-44, thank her and terminate the interview.

\section{To be filled in by screener}

\section{Screening Questions}

Note: Be sure to include reason for

visit in required services.

\begin{tabular}{|c|c|c|c|c|}
\hline & & \multicolumn{2}{|l|}{ Service(s) } \\
\hline \multicolumn{2}{|r|}{ What is the reason for today's visit? } & \multicolumn{2}{|l|}{$\begin{array}{l}\text { Reason for the visit: } \\
\text { accination }\end{array}$} & 1. Provided \\
\hline 1 & $\begin{array}{l}\text { Are you pregnant? } \\
\text { 1. Yes } \rightarrow \\
\text { No go to } 2\end{array}$ & $\begin{array}{l}\text { Are you attending a prenatal clinic? } \\
\text { 1. No } \rightarrow \\
\text { 2. Yes: go to } 5\end{array}$ & $\begin{array}{l}\text { Prenatal Care } \\
\text { and go to } 5\end{array}$ & $\begin{array}{l}\text { 1. Provided } \\
\text { 2. Scheduled } \\
\text { 3. Referral }\end{array}$ \\
\hline 2 & 2. Yes: go to 4 & $\begin{array}{l}\text { Are you using a contraceptive method? } \\
\text { 2. Yes: go to } 3\end{array}$ & $\begin{array}{l}\text { Family Planning } \\
\text { and go to } 4\end{array}$ & $\begin{array}{l}\text { 1. Provided } \\
\text { 2. Scheduled } \\
\text { 3. Referral }\end{array}$ \\
\hline 3 & $\begin{array}{l}\text { Are you happy with your } \\
\text { contraceptive method? } \\
\text { 1. No } \rightarrow \\
\text { 2. Yes: go to } 4\end{array}$ & $\begin{array}{l}\text { Would you like to use another } \\
\text { contraceptive method? } \\
\text { 1. Yes } \rightarrow \\
\text { 2. No: go to } 4\end{array}$ & $\begin{array}{l}\text { Family Planning } \\
\text { and go to } 4\end{array}$ & $\begin{array}{l}\text { 1. Provided } \\
\text { 2. Scheduled } \\
\text { 3. Referral }\end{array}$ \\
\hline 4 & $\begin{array}{l}\text { When did you have your last pap } \\
\text { smear for cervical cancer? } \\
\text { 1. DK/more than } 3 \text { years ago } \rightarrow \\
\rightarrow \text { tess than } 3 \text { years ago go to } 5\end{array}$ & $\begin{array}{l}\text { Would you like to have a } \\
\text { pap smear today? } \\
\text { 1. Yes } \rightarrow \\
\text { 2. No: go to } 5\end{array}$ & $\begin{array}{l}\text { Pap Smear } \\
\text { and go to } 5\end{array}$ & $\begin{array}{l}\text { 1. Provided } \\
\text { 2. Scheduled } \\
\text { 3. Referral }\end{array}$ \\
\hline 5 & $\begin{array}{l}\text { Do you have any children less } \\
\text { than } 5 \text { years of age? } \\
\text { 2. No: go to } 7\end{array}$ & $\begin{array}{l}\text { Are you taking them in for well child } \\
\text { services and growth monitoring? } \\
\text { 2. Yes: go to } 6\end{array}$ & $\begin{array}{l}\text { Growth and } \\
\text { Development } \\
\text { Evaluation } \\
\text { and go to } 6\end{array}$ & $\begin{array}{l}\text { 1. Provided } \\
\text { 2. Scheduled } \\
\text { 3. Referral }\end{array}$ \\
\hline 6 & $\begin{array}{l}\text { Have all your children under age } 5 \\
\text { been completely vaccinated? } \\
\text { 1. No/DK } \rightarrow \\
\text { 2. Tesigo to } 7\end{array}$ & $\begin{array}{l}\text { Would you like to schedule vaccination } \\
\text { for your child(ren)? } \\
\text { 1. Yes } \rightarrow \\
\text { 2. No: go to } 7\end{array}$ & $\begin{array}{l}\text { Vaccination } \\
\text { and go to } 7\end{array}$ & $\begin{array}{l}\text { 1. Provided } \\
\text { 2. Scheduled } \\
\text { 3. Referral }\end{array}$ \\
\hline 7 & $\begin{array}{l}\text { Is there any other service you } \\
\text { would like to receive today, or } \\
\text { would like to be referred for? } \\
\text { 1. Yes } \rightarrow \\
\text { 2No: End interview }\end{array}$ & List service(s) & & $\begin{array}{l}\text { 1. Provided } \\
\text { 2. Scheduled } \\
\text { 3. Referral }\end{array}$ \\
\hline \multicolumn{5}{|c|}{ Observations (screener): } \\
\hline \multicolumn{5}{|c|}{ Observations (provider): } \\
\hline
\end{tabular}

*Note: The fourth column on service outcome is not filled in. This should be filled in by the provider for the records. 


\section{Day 2}

Experience across countries shows that including a second day of training leads to more effective implementation of the systematic screening intervention as proper screening techniques are reinforced with more practice.

The second day is devoted to supervised practice with clinic clients in the staff's own work sites. Clients will be asked to allow the staff to screen for their reproductive and child health needs. The staff member will do the screening and fill out the instrument, which will then be conveyed to the provider. The supervisor will now take on her supervision role, follow the staff member's questions, and give her feedback.

It is important to understand that once the client has been screened, even though this is only a part of training, she needs to have a response to all identified service needs. Services to meet these needs must be offered to the client either during the same visit, by an appointment for a future visit at the clinic, or by referral to another clinic that provides the needed service.
The trainer must take the necessary time after each screening to discuss the trainees' performance (provider and supervisor) during that particular screening and help correct any deficiency detected. This sequence will be repeated until the staff and supervisor are proficient in all stages of the screening and service procedure. The trainer will be responsible for certifying that the staff is sufficiently competent to be allowed to screen clients during service delivery. Staff should screen a minimum of five clients or simulated clients to be considered competent.

To conclude the training, trainers can reinforce providers' motivation to screen through group discussion on their experiences including:

The number of unmet needs detected.

Women's responses to the offer of additional services.

Any problems encountered and potential solutions. 


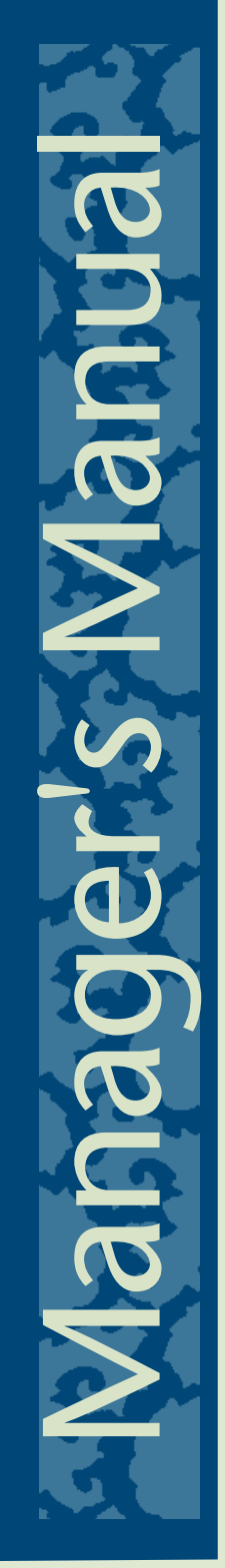

